\title{
The Business Alteration for Tobacco Farmers: Lessons from Rural Area in Indonesia
}

\author{
Retna Ngesti SEDYATI $^{1}$, Ery Tri DJATMIKA ${ }^{2}$, Hari WAHYONO ${ }^{3}$, Sugeng Hadi UTOMO ${ }^{4}$
}

Received: July 06, 2019 Revised: September 16, 2019 Accepted: September 24, 2019

\begin{abstract}
The study aims to analyze the adaptation strategies and resilience of tobacco farmers to face unfavorable trading system. The research method refers to a qualitative approach with phenomenological models and case studies. The findings revealed tobacco farmers in Jember developed various adaptation strategies and resilience through farmer group organizations, partnerships, self-capacity building and access to financial institutions based on economic, social, cultural, and experience values from various sources and interactions among fellow tobacco farmers. The tobacco trading system, which is left to the market mechanism, results in low bargaining power of farmers, this encourages tobacco farmers to develop various adaptation and survival strategies, namely through collective activities of farmer groups, partnerships and self-development and access to financial institutions. Dealing with the unfavorable tobacco trading system, tobacco farmers do not switch to other commodity farming but adapt and make Jember a center for tobacco production in East Java and Indonesia. From this findings, it suggests to the government as the regulator does not only provide subsidies for tobacco farmers, but also must provide various technical assistance to increase the ability of tobacco farmers. More importantly, regulations must be made benefit tobacco farmers other than corporations so that equality can be enjoyed by tobacco economy players.
\end{abstract}

Keywords : Farmers Alteration, Resilience, Trading Systems, Tobacco Business, Indonesia

JEL Classification Code : M21, Q12

\section{Introduction}

Tobacco is a raw material for the manufacture of cigarettes and cigars. The tobacco industry contributes significantly to state revenues through exports and foreign exchange, tax revenues and providing employment. Tobacco

1 First Author, Doctoral Program in Economics Education, Universitas Negeri Malang and FKIP Universitas Jember, Indonesia. Email: retnasedyati.fkip@unej.ac.id

2 Department of Development Economics, Faculty of Economics, Universitas Negeri Malang, Indonesia. Email: ery.tri.fe@um.ac.id

3 Department of Development Economics, Faculty of Economics, Universitas Negeri Malang, Indonesia.

Email: hari.wahyono.fe@um.ac.id

4 Corresponding Author, Department of Development Economics, Faculty of Economics, Universitas Negeri Malang, Indonesia. [Postal Address: Jalan Semarang 5, Malang, East Java 65145, Indonesia] Email: sugeng.hadi.fe@um.ac.id

(c) Copyright: Korean Distribution Science Association (KODISA)

This is an Open Access article distributed under the terms of the Creative Commons Attribution Non-Commercial License (http://Creativecommons.org/licenses/by-nc/4.0/) which permits unrestricted noncommercial use, distribution, and reproduction in any medium, provided the original work is properly cited. control through increasing taxes will have a dual effect, to wit increasing state revenues and reducing smoking habits. FAO and WHO seek a big dilemma to weigh the social and economic costs of smoking towards economic and social benefits (Kinman \& Vinten, 1995). Amid the efforts in limiting the consumption of tobacco, the rate of cigarette sales in Indonesia is increasing. The provisions in the road map for the level of production of tobacco products reached 260 billion sticks of cigarettes in 2020 was achieved in 2014 (Krisnamurthi, 2015). In 2020, the production is projected to reach 524.2 billion cigarettes. It indicates that there will be a lot of tobacco is needed as raw material Industry (BPS, 2016).

The tobacco industry and exporters take the benefit of the rapid growth of production and consumption and doubled profits, but it is not followed by the improvement of the farmers' prosperity. However, tobacco farmers are at the forefront of the tobacco trading system. Approximately 60 percent of the economic value of tobacco occurred at the merchant level, while among farmers only get about 19 percent (IISD, 2015). It illustrates how tobacco farmers are 
the most vulnerable groups and have low bargaining power in the supply chain of tobacco trading system. The weak position of farmers compared to the merchant are caused by the long chain of the tobacco trading system and oligopoly.

The area that is the largest tobacco producer in Indonesia is East Java Province in Indonesia where Jember Regency (BPS, 2016), Indeed, Astuti (2016) revealed that tobacco farmers cannot sell their crops directly to large traders, especially to cigarette factories/exporters, but must go through middlemen. This is because cigarette factories only accept large purchases. Middleman is an extension of large traders to buy tobacco from farmers, from wholesalers hereinafter tobacco sold to cigarette factories/exporters. There are a few large farmers who also take role as middlemen so that they can directly sell to the large traders. In selling tobacco harvests, the quality and price are determined by middlemen not farmers as sellers, likewise weighing the weight of tobacco as well middlemen usually take 5 to 10 percent of the amount of tobacco sold by farmers on the grounds as transportation costs to wholesalers/exporters. In contrast to other items that determine the price and those that weigh merchandise are sellers. That is the condition experienced by tobacco farmers, namely as a less profitable party.

Priyono and Yuswardi (2013) revealed that although tobacco farmers in Jember facing the unfavorable tobacco trading system but tobacco farmers in Jember are reluctant to switch to other crops. It shows that tobacco farmers in Jember will not change their profession or labor transformation and switching to non-tobacco sector even when they faced unfavorable things. Instead, tobacco farmers in Jember choose to resilience and to find a mechanism of adaptation to deal with the problems of tobacco principally relating to the tobacco trading system. In addition, Trostle (1986) stated that adaptation as a strategy used by humans in their lifetime to anticipate changes in both physical and social environment. Moglia, Cork, Boschetti, Cook, Bohensky, Muster, and Page (2018) stated that adaptation is understood as a process of change responsiveness that enhance the ability of a system to achieve the desired goal. Bennett (1966) stated that adaptation is a process of mutual human relations with the physical environment that these individuals are trying to adjust their behavior in accordance with the challenges of the physical environment.

Adaptation occurs because of the influence of some factors such as socio-economic, cultural, political, geographic, ecological and institutional form of human interaction with the environment (Eriksen, Aldunce, Bahinipati, Martins, Molefe, Nhemachena, \& Ulsrud, 2011). Hilmanto (2010) in adaptation, the human is more directed at changing attitudes and culture in response to the surrounding environment. On certain condition, humans are being forced to adapt to meet their needs with the limitations that exist in the surrounding environment. Humans have the ability of adaptation and how-adaptation and different interactions that are passed from generation to generation.
Abdoellah (1990) said that the ability of an individual to adapt has value for their viability. It implies that the greater of the adaptability of a living creature, the greater the tendency of the creatures live. Garna (1996) stated that motivation is the most important energy in bringing farmers to adapt to environmental conditions. Someone who has a high motivation to have passion and energy that is very abundant and strong, so that farmers are highly motivated to be more adaptable. Geertz (1976) asserted that the characteristics of the adaptation of a community depend on the struggle or their ingenuity to defeat environment.

Tobacco is referred to Gold Leaves, but tobacco farmers faced many problems from upstream to downstream that enchain them to enjoy the maximum results and still have to bear the complex risks. Tobacco is an icon and a superior product of Jember, but various government regulations do not favor tobacco farmers. In the midst of the paradox that accompanies tobacco commodity farming, tobacco farmers in Jember in their economic activities persist to plant tobacco and make various adaptations. Therefore, this study intended to examine the strategies of adaptation and resilience of farmers to face tobacco trading system in Jember.

\section{Methodology}

This study was conducted using a qualitative approach, applying phenomenology to uncover the meaning of adaptation and resilience of tobacco farmers in Jember. The study was conducted in Jember district that includes the Sub-district Kalisat, Jelbuk, Ambulu, and Wuluhan as the area of tobacco production centers. Key informants as a source of the research data are rural tobacco farmers who have narrow-land farmer, medium-land farmer and also an extensive-land farmer with the following criteria, has been cultivating tobacco for 10 years continuously and completely understand the information relating to the adaptation and durability of tobacco farmers in the region.

The data collection was gathered by using in-depth interviews, participant observation, and documentation. Data analysis was performed through inductive analysis of data reduction, data display and conclusion with interpretative way, as shown in Figure 1. 


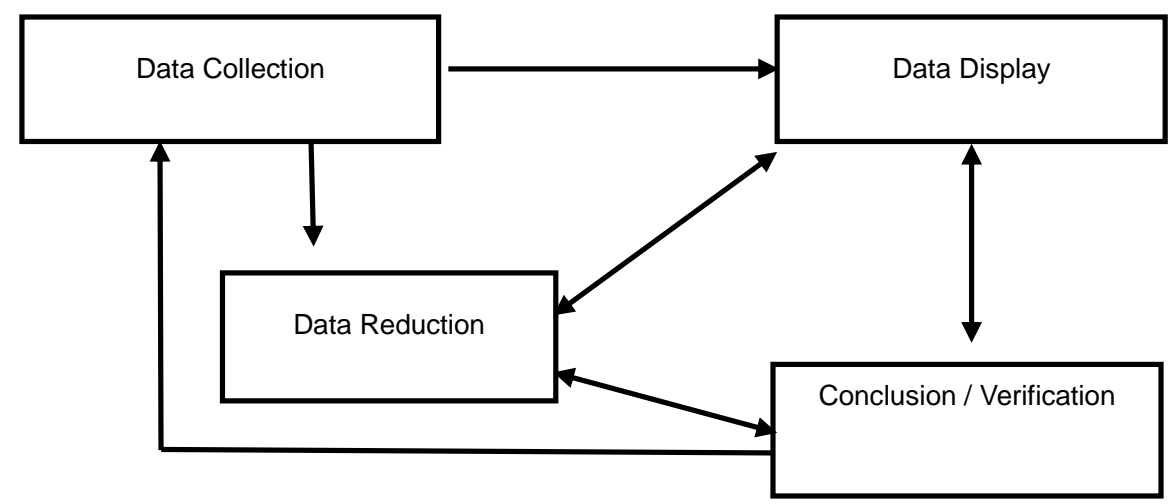

Source: Miles \& Huberman (2010)

Figure 1: Data Analysis Diagram

Data obtained from the field needs to be analyzed through data reduction, the aim is to summarize, sort and choose to focus on matters relating to the theme of research and look for patterns in accordance with the focus of research. In data reduction, the main data is categorized. The next step in presenting data (data display), is done in the form of brief descriptions, charts, relationships between categories, or other. Hence, what is commonly done in qualitative research is the presentation of data in the form of narrative texts. After the data is categorized, arranged in a relationship pattern, then the next step is drawing conclusions.

\section{Results and Discussion}

The research findings revealed some of the strategies and mechanisms of adaptation of farmers to grow tobacco persisted even though they faced with an unfavorable trading system. The adaptation strategy carried out by tobacco farmers in Jember is not static, but dynamic by taking into account the contemporary situation and conditions faced by tobacco farmers.

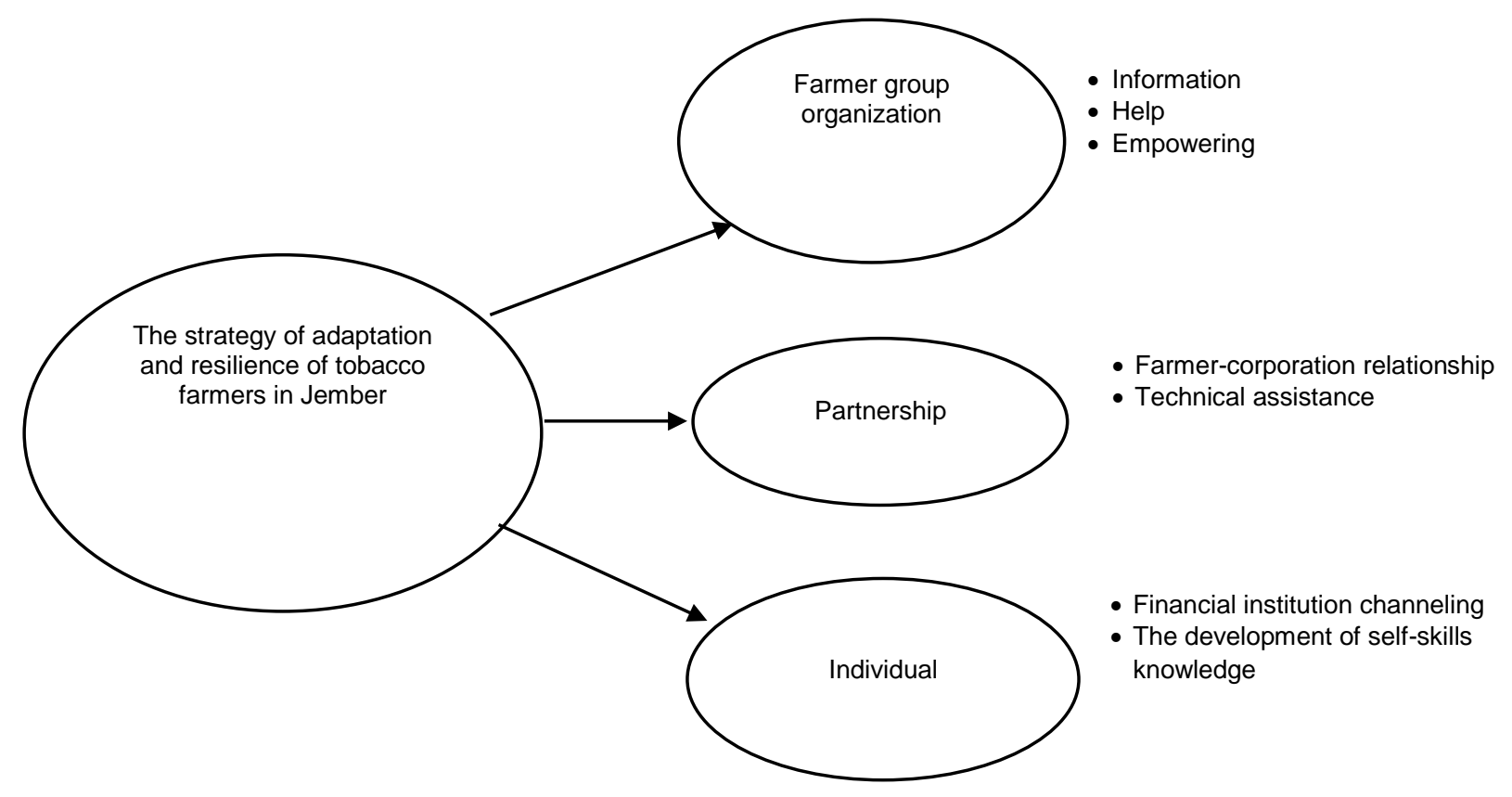

Figure 2: The Variety of Adaptation and Resilience Strategies of Tobacco Farmers in Jember 


\subsection{The Strategy of Farmers Group Organization}

Adaptation strategy by farmers is through institutional organizations by becoming a member of farmers group. Adaptation and resilience strategies through farmer group provide benefits to farmers: (1) Access of information provided by the agency through the agricultural extension field at the beginning of the planting season of tobacco to members of farmer group not to the individual farmers is related to the quality and quantity of tobacco which is needed by the cigarette manufacturer/exporter, and weather forecasts. It is intended to the farmers can adjust the extensive of planting area to prevent over products that caused low price. (2) Access to fertilizer subsidy assistance. Farmers can buy fertilizer at lower prices through farmer groups than buying individually. (3) Through farmer groups, farmers get assistance in production techniques, recommended fertilizer and drug socialization so that the quality of tobacco is in accordance with what is expected by cigarette manufacturers/ exporters. (4) The joining of farmers in farmer groups fosters strong kinship among members, namely mutual cooperation, in farming activities and outside the business of farming so as to provide the power to deal with tobacco trading that is less profitable.

\subsection{Partnership Strategic}

Partnerships are strategies and mechanisms of adaptation that can improve the bargaining position of farmers. The partnership pattern between tobacco farmers and cigarette companies/exporters in Jember is based on a cooperation contract. Partner farmers get capital assistance, agricultural facilities and infrastructure, and guaranteed sales. In addition to getting information and technical assistance for good farming practices (Good Agricultural Practices - GAP) to improve tobacco quality, efficiency and productivity. Partner farmers also get an explanation of the types of drugs used because tobacco that will be sent to Europe and America, Na-Oogst tobacco requires a residual threshold of pesticides that are used so that production is not rejected by presupposed foreign markets.

The partnership will also make strong family bound between farmers and partner companies, in addition to farmers obtaining capital loans farmers also get funding loans to celebrate the Eid holiday. The attitude of partner companies such as this makes loyal partner farmers hold firm to the agreement, farmers will continue to sell their crops to partner companies even though many other traders will buy at higher prices.

For those who are not partnering, they sell crops to traders/middlemen, farmers will face price uncertainty, prices will be swayed by middlemen. Middlemen in this term is the term tobacco trader in Jember who came to farm houses to buy tobacco. Middlemen often spreads issues that are worrying to farmers, that the cigarette warehouse is no longer open, the warehouse stock is full and so forth that make farmers who do not have a storage warehouse will sell their goods even though the price given by the holder is low.

\subsection{Self-Capacity Development Strategies and Financial Institution Channeling}

Developing self-capacity gathered information from various sources in order to improve self-ability in tobacco farming. Young farmers in general, besides receiving information from fellow tobacco farmers, also seek knowledge and skills in tobacco farming from the internet media, electronic media and social media and then learn, discuss with other farmers, and practice it.

Fluctuations in tobacco prices are high, if the price received by farmers is low which results in losses, farmers will take loans to banks, as this is one of the adaptation strategies undertaken. Tobacco farmers individually open channeling with existing financial institutions, namely Bank Rakyat Indonesia (BRI) or Bank Negara Indonesia (BNI). Tobacco commodity has many risks and uncertainties. When the price is good, 1 quintal which has standard quality tobacco Na-Oogst (NO) reaches 10 million -13 million Rupiah. When the stuff is very nice, 1 quintal could reach $20 \mathrm{M}$, in reverse, when in bad price it is just around 5-6 million per quintal. The condition shows the uncertainty of tobacco's price. Make a debt to the bank as a capital of replanting tobacco, because the loss in tobacco farming must be pursued by continuing to plant tobacco, it cannot be covered by planting other commodities such as rice or corn.

Large farmers are generally familiar with borrowing money from the bank as capital, this loan will be returned after harvest, if it turns out the return crop loses usually farmers will sell their assets that are mobile, not non-mobile assets because the value of non-mobile assets such as land, rice fields and so forth will be able to continue to rise. For small farmers in general, they are still not familiar with banking, usually they borrow from their already known middlemen in the form of livestock or money.

The strategy of adaptation and resilience of farmers in tobacco farming in dealing with the developed commerce is varies, including the collective action of joining a farmer group. As in Regulation of The Minister of Agriculture No. 67 of 2016 concerning the function of farmers group as a learning class, farmers group is a place for teaching and learning for members to improve their knowledge, skills and attitudes to grow and develop through the use and access to information and technology so that they can increase productivity, income, and a better life. Farmers group also functions as a vehicle for work both among fellow farmers in Farmers group and between Farmers group and with other parties, hence farming is expected to be more efficient and able to face threats, challenges, and obstacles so that it is more profitable. This explanation is similar to Huang and Qiao (2015) that the existence of farmer organizations will benefit the development of better agriculture. 
The results of the Nyareza \& Dick (2012) study that agricultural extension service programs were unsatisfactory because they could not reach all farm households, the joining of farmers in a communication community could be the solution. Nyareza and Dick (2012) found in this study that young farmers in the communication community discussed in getting fertilizer and farming practices. Huang and Qiao (2015) statement that the joining of tobacco farmers in an organization has implications for increasing the bargaining power of farmers in dealing with various problems, especially trade and climate change. It is in line with the statement of Nuryanti and Swastika (2016) that the formation of groups is to improve the bargaining position of farmers. The collective action of tobacco farmers in Jember, which is manifested in the Farmers group organization, makes the farmer's position more vis-à-vis cigarette companies or large-scale tobacco traders. It can be likened to a broomstick when it is alone and not bound together, it will be easily broken or broken. However, when bound together in one institutional bond, it becomes strong and cannot be broken or broken.

In addition to increasing bargaining power, the results of the study also show that through farmer groups important information will be obtained from the agency about the quantity and quality of tobacco needed by cigarette manufacturers/exporters so that farmers can adjust the quantity of production by arranging the extent area of planting, do not let farmers plant more than the needs of cigarette factories/exporters because it will reduce prices, this is in accordance with the theory of demand and supply by Sukirno (2013) that one of the factors that affect the price level is the number of offers. If the number of offers is high while the number of requests is fixed, thus the price will go down.

Another adaptation strategy found in this study is to form a partnership pattern that is between farmers and cigarette companies/exporters. For farmers, partnerships will provide price certainty and sales certainty, and conversely for farmers who are not partners, traders often sway prices and spread the issue of tobacco quality that is not according to factory demand and issues that the factory is closed because the stock is sufficient. Through partnership farmers also get capital loans and loan funds to celebrate Eid holidays from partner companies, similarly, Bagdoniene and Zilione (2009) stated that to make functional and successful business relationships the need to build personal relationships and openness between buyers and sellers.

Research on partnerships was also carried out by Zhang, $\mathrm{Hu}, \mathrm{Li}$, and Pradhan (2018) in Lujiang Flatland China, that the Partnership mechanism has the potential to mobilize funds from various sources and benefit local knowledge, and reduce uncertainty. Moreover, Zhang et al. (2018) in his findings that through partnerships in the form of patron relationships clients of tobacco farmers can resilience and adapt to trading systems. Patron can provide guidance and protection in dealing with tobacco trading.

On the other hand, farmers who are not partnering, they will be able to freely choose traders who provide high prices even though on the other hand accept price uncertainty, in general they are large farmers, they have a land area of more than 2 hectares, have large capital, have a warehouse for product storage will be issued when the warehouse is short of stock so they have little power to determine the price then affect the income earned. Franzel (1999) that the amount of income will positively correlate with the mechanism of agricultural adaptation.

Being in debt is an adaptation strategy of farmers to be able to continue to grow tobacco when farmers experience losses due to low prices. Deressa, Hassan, and Ringler (2011) that the availability of credit will facilitate cost constraints and allow farmers to buy inputs such as seeds and fertilizers so that there is a positive relationship between the level of adaptation and availability of credit. In addition to debt they also sometimes sell assets such as cars or motorbikes. In the same way, Marzali (2003), adaptation strategies are human behavior in allocating resources what they have in dealing with problems as choices of appropriate actions according to the social, cultural, economic and ecological environment in the place where they live.

Apart from the three strategies of adaptation of tobacco farmers, some farmers develop what researchers call cultivation sensitivity. Sensitivity is influenced by experience as revealed by Kebede, Gunjal, and Coffin (1990) that there are positive relationship between the number of years of experience in agriculture and an increase in adaptation in agricultural activities. In this study, a tobacco farmer revealed that farming experience provides farmer sensitivity by looking at the number of seeds, if the availability of seedlings means that planting tobacco is high, on the contrary if the availability of excess seeds means that those who grow tobacco are few, based on this or more adjusting conditions to get high product prices.

\section{Conclusion}

The tobacco trading system, which is left to the market mechanism, results in low bargaining power of farmers, this encourages tobacco farmers to develop various adaptation and survival strategies, namely through collective activities of farmer groups, partnerships and self-development and access to financial institutions. Dealing with the unfavorable tobacco trading system, tobacco farmers do not switch to other commodity farming but adapt and make Jember a center for tobacco production in East Java and Indonesia. From this findings, it suggests to the government as the regulator does not only provide subsidies for tobacco farmers, but also must provide various technical assistance to increase the ability of tobacco farmers, more importantly regulations must be made that also benefit tobacco farmers other than corporations so that equality can truly be enjoyed by tobacco economy players. 


\section{References}

Abdoellah, O. S. (1990). Indonesian transmigrant and adaption: A ecological antropological perspective $(\mathrm{PhD}$ Dissertation). University of California, Berkeley, California.

Astuti, D. D. (2017). Economic potential mapping analysis in the district of Jember. Relasi: Jurnal Ekonomi, 13(1), 16-33.

Bagdoniene, L., \& Zilione, R. (2009). Business to business relationships: The variables in the context of success. Social Sciences, 66(4), 16-25.

Bennett, M. R. (1966). Rebound excitation of the smooth muscle cells of the Guinea-Pig Taenia Coli after stimulation of intramural inhibitory nerves. The Journal of Physiology, 185(1), 124-131.

BPS. (2016). Analisis data Tembakau Provinsi Jawa Timur 2016. Indonesia: Provinsi Jawa Timur.

Deressa, T. T., Hassan, R. M., \& Ringler, C. (2011). Perception of adaptation to climate change by farmers in the Nile Basin of Ethiopia. The Journal of Agricultural Science, 149, 23-31.

Eriksen, S., Aldunce, P., Bahinipati, C. S., Martins, R. D. A., Molefe, J. I., Nhemachena, C., \& Ulsrud, K. (2011). When not every response to climate change is a good one: Identifying principles for sustainable adaptation. Climate and Development, 3(1), 7-20.

Franzel, S. (1999). Socioeconomic factors affecting the adoption potential of improved tree fallows in Africa. Agroforestry Systems, An International Journal Incorporating Agroforestry Forum, 47(1/3), 305-321.

Garna. (1996). Sistem Budaya Indonesia. Bandung, Indonesia: Program Pascasarjana UNPAD.

Geertz, C. (1976). Involusi Pertanian. Jakarta, Indonesia: Bharata KA Publisher.

Hilmanto, R. (2010). Etnoekologi. Bandar Lampung, Indonesia: Penerbit Universitas Lampung.

Huang, V., Vyas, V., \& Qiao, L. (2015). Farmer and organization in China and India. China Agriculture Economic Review, 7(4), 601-615.

Kebede, Y., Gunjal, K., \& Coffin, G. (1990). Adoption of new technologies in Ethiopian agriculture: The case of Tegulet-Bulga District Shoa Province. Agricultural Economics, 4(1), 27-43.

Kinman, B. F., \& Vinten, G. (1995). Tobacco: Policing and social policy. International Journal of Sociology and Social Policy, 15(4/5), 59-112.

Krisnamurthi, B. (2015). Paradoks Peran Petani Tembakau Dalam Sistem Industri Rokok, dalam Asep Mulyana (Ed). Petani tembakau di Indonesia: Sebuah Paradoks kehidupan.

Marzali, A. (2003). Strategi Peisan Cikalong Dalam Menghadapi Kemiskinan, Jakarta, Indonesia: Yayasan Obor Indonesia.

Miles, M. B., \& Huberman, A. M. (2010). Qualitative data analysis (2nd Ed). Newbury Park, CA: Sage Publication.

Moglia, M., Cork, S. J., Boschetti, F., Cook, S., Bohensky, E., Muster, T., \& Page, D. (2018). Urban transformation stories for the 21st century: Insights from strategic conversations. Global Environmental Change, 50, 222237.

Nuryanti, S., \& Swastika, D. K. S. (2016). Peran Kelompok Tani Dalam Penerapan Teknologi Pertanian. In Forum penelitian agro ekonomi, 29(2), 115-128.

Nyareza, S., \& Dick, A. L. (2012). Use of community radio to communicate agricultural information to Zimbabwe's peasant farmers. In Aslib Proceedings, 64(5), 494-508.

Priyono, A., \& Yuswadi, H. (2013). Nilai-nilai Kebertahanan Petani Tembakau. Artikel Hasil Penelitian Mahasiwa, 15.

Sukirno, S. (2013). Pengantar Teori Mikro Ekonomi Edisi Ketiga. Jakarta, Indonesia: PT.Raja Grafindo Persada.

Trostle, J. (1986). Anthropology and epidemiology in the twentieth century: A selective history of collaborative projects and theoretical affinities, 1920 to 1970 . In Anthropology and Epidemiology (pp. 59-94). Dordrecht, Netherlands: Springer.

Zhang, L., Hu, J., Li, Y., \& Pradhan, N. S. (2018). Publicprivate partnership in enhancing farmers' adaptation to drought: Insights from the Lujiang Flatland in The $\mathrm{Nu}$ River (Upper Salween) Valley, China. Land Use Policy, $71,138-145$. 